\title{
VOLUME TEGAKAN Acacia mangium PADA UJI PEROLEHAN GENETIK DENGAN KERAPATAN TEGAKAN TINGGI
}

Stand volume of Acacia mangium in high stand density for genetic gain trial

\author{
Dwi Kartikaningtyas, Teguh Setyaji, dan Arif Nirsatmanto \\ Balai Besar Penelitian dan Pengembangan Bioteknologi dan Pemuliaan Tanaman Hutan \\ Jl. Palagan Tentara Pelajar Km. 15, Purwobinangun, Pakem, Sleman, Yogyakarta, Indonesia \\ email: akitrak@gmail.com
}

Tanggal diterima: 13 Februari 2017, Tanggal direvisi: 22 Februari 2017, Disetujui terbit: 16 November 2017

\begin{abstract}
High initial stand density is commonly practiced in forest plantations subjected to produce high quality logs through successive thinnings. In this study, genetically improved seed of Acacia mangium was verified in genetic gain trial using high initial stand density. The trial was established in Jonggol, West Java and laid out in randomized complete block design with high initial stand density of 2500 trees/ha or in spacing of $2 \times 2 \mathrm{~m}$. The improved seeds tested in the trial were collected from four seedling seed orchards (SSOs). As a control, unimproved seeds from seed production area (SPA) were also planted together in the trial. The assessment of stand volume productivity was periodically conducted at two, three and four years of age. The results of study showed that the improved seeds from the four SSOs out performed the unimproved one. However, the significant difference among the seed sources was initially found at the four years of age. The average stand volumes of improved seed were $58.56 \mathrm{~m} 3 / \mathrm{ha}, 94.87 \mathrm{~m} 3 / \mathrm{ha}$ and $163.8 \mathrm{~m} 3 / \mathrm{ha}$ for two, three, and four years of age, respectively. The superiority of improved seed over the unimproved one ranged from 23\%-36\% (two years), 6\%-30\% (three years) and 2\%-22\% (four years). The four SSOs showed different behaviours in response to high stand density. Improved seed from SSOs with higher selection intensity was likely to be more tolerant to high stand density.
\end{abstract}

Keywords: tree improvement, genetically improved seed, realized genetic gain, seedling seed orchad

\begin{abstract}
ABSTRAK
Kerapatan awal tegakan yang tinggi yang diikuti dengan tindakan penjarangan pada umumnya banyak diterapkan pada penanaman dengan tujuan untuk menghasilkan kualitas batang kayu yang lebih baik. Pada penelitian ini, produktivitas benih unggul Acacia mangium diuji lebih lanjut pada plot uji perolehan genetik dengan kerapatan awal tegakan yang tinggi. Uji perolehan genetik dibangun di Jonggol, Jawa Barat pada kerapatan awal tegakan yang tinggi yaitu 2500 pohon/ha atau jarak tanam 2 × 2 m menggunakan rancangan acak lengkap berblok. Benih unggul yang diuji berasal dari empat kebun benih semai (KBS), dan sebagai kontrol adalah benih tidak termuliakan dari areal produksi benih (APB). Pengukuran volume tegakan dilakukan secara berkala pada umur dua, tiga dan empat tahun. Hasil penelitian menunjukkan bahwa benih unggul yang berasal dari empat KBS memiliki produktivitas volume tegakan yang lebih baik dibandingkan dengan benih yang tidak dimuliakan. Namun demikian, perbedaan yang nyata antar sumber benih mulai ditemukan pada umur empat tahun. Rata-rata volume tegakan dari benih unggul adalah 58,56 m3/ha; 94,87 m3/ha dan 163,8 $\mathrm{m} 3 /$ ha secara berurutan pada umur dua, tiga dan empat tahun. Superioritas benih unggul dibandingkan benih tidak termuliakan berkisar antara 23\%$36 \%$ (2 tahun), 6\%-30\% (3 tahun) dan 2\%-22\% (4 tahun). Keempat KBS menunjukkan pertumbuhan volume tegakan yang berbeda dalam memberikan respon terhadap kerapatan tegakan yang tinggi. Benih unggul dari KBS dengan intensitas seleksi yang lebih tinggi cenderung lebih tahan terhadap kerapatan tegakan yang tinggi.
\end{abstract}

Kata kunci: pemuliaan pohon, benih unggul, perolehan genetik aktual, kebun benih semai

\section{PENDAHULUAN}

Acacia mangium Willd., merupakan salah satu jenis tanaman cepat tumbuh yang mampu beradaptasi pada tanah masam $/ \mathrm{pH}$ rendah (Hardiyanto, 2004) maupun pada lahan yang kurang subur terutama pada lahan bekas padang alang-alang (Pinyopusarerk, Gunn, \& Liang, 1993). Keunggulan lain yang dimiliki oleh $A$. mangium adalah sifat kayu yang baik sebagai bahan baku pulp, kayu pertukangan, konstruksi ringan dan relatif tahan terhadap hama dan penyakit (Hardiyanto, 2004; Harwood, Hardiyanto, \& Yong, 2015). Mengingat keunggulannya, jenis ini banyak digunakan dalam pengembangan Hutan Tanaman Industri (HTI) di Indonesia sebagai bahan baku dalam pembuatan pulp (Hardiyanto \& Nambiar, 2014). 
Sementara itu, di beberapa daerah pengembangannya di pulau Jawa, A. mangium banyak dimanfaatkan sebagai bahan baku kayu pertukangan.

Upaya pemuliaan A. mangium terus dilakukan oleh berbagai pihak untuk meningkatkan produktivitas tegakan dalam memenuhi kebutuhan bahan baku kayu yang terus semakin meningkat. Balai Besar Penelitian dan Pengembangan Bioteknologi dan Pemuliaan Tanaman Hutan (BBPPBPTH) sejak tahun 1994 secara komprehensif telah melakukan serangkaian kegiatan pemuliaan A. mangium melalui pembangunan Kebun Benih Semai generasi pertama (KBS F-1) dan dilanjutkan dengan generasi kedua (KBS F-2) yang tersebar di beberapa lokasi di Indonesia (Hashimoto, Kurinobu, \& Suhaendi, 1996; Kurinobu \& Rimbawanto, 2002). Benih unggul hasil pemuliaan yang dilakukan telah banyak digunakan dalam penanaman operasional Hutan Tanaman Industri (HTI) di Indonesia (Hardiyanto, 2004; Hastanto, 2010; Nirsatmanto, Setyaji, Sunarti, \& Kartikaningtyas, 2015).

Upaya untuk mendapatkan informasi besarnya peningkatan produktivitas, benih unggul hasil pemuliaan perlu diuji dan diverifikasi lebih lanjut pada suatu plot uji perolehan genetik (genetic gain trial). Beberapa penelitian uji perolehan genetik benih unggul hasil pemuliaan A. mangium pada beberapa tapak telah dilaporkan, khususnya dengan baku mutu penanaman untuk kebutuhan bahan baku pulp (Hastanto, 2010; Leksono, Nirsatmanto, Wahyuningtyas, \& Sofyan, 2007; Nirsatmanto \& Setyaji, 2013; Nirsatmanto et al., 2015; Nirsatmanto, Setyaji, \& Wahyuningtyas, 2014). Namun demikian pengujian perolehan genetik A. mangium dengan baku mutu untuk kayu pertukangan belum banyak dilaporkan, khususnya berkaitan dengan kerapatan tegakan tinggi yang diikuti dengan tindakan penjarangan.

Jarak tanam awal yang rapat yang diikuti dengan penjarangan secara bertahap merupakan salah satu teknik silvukultur yang banyak digunakan dalam meningkatkan kualitas batang dan kayu tebangan untuk bahan baku kayu pertukangan. Untuk mendapatkan informasi tingkat ketahanan benih unggul A. mangium terhadap kerapatan tegakan, telah dibangun petak uji perolehan genetik (genetic gain trial) A. mangium dengan kerapatan tegakan 2500 pohon/hektar atau jarak tanam $2 \mathrm{~m} \mathrm{x} 2 \mathrm{~m}$ di Jonggol, Jawa Barat (Nirsatmanto, Setyaji, \& Surip, 2009). Dalam penelitian ini dilakukan penilaian produktivitas volume tegakan pada petak uji perolehan genetik untuk mengetahui efektivitas kerapatan tegakan yang tinggi dalam meningkatkan produktivitas A. mangium pada umur dua, tiga, dan empat tahun.

\section{BAHAN DAN METODE}

\section{A. Lokasi dan waktu penelitian}

Penelitian ini dilakukan di petak uji perolehan genetik A. mangium di Jonggol, Jawa Barat (Tabel 1). Pengambilan data dilakukan pada saat tegakan berumur dua, tiga, dan empat tahun setelah tanam yaitu pada tahun 2011, 2012 dan 2013.

\section{B. Bahan dan alat}

Bahan yang digunakan pada penelitian ini adalah tegakan $A$. mangium yang terdapat di petak uji perolehan genetik. Petak uji dibangun dengan menggunakan benih yang berasal dari sumber benih yang sudah termuliakan, yaitu berasal dari kebun benih semai (KBS), dan benih yang belum termuliakan, yaitu areal produksi benih (APB) sebagai kontrol (Tabel 2).

Alat-alat yang digunakan dalam penelitian meliputi: galah ukur sebagai alat pengukur tinggi tanaman, pita diameter sebagai alat pengukur diameter batang, dan komputer sebagai alat analisis data.

\section{Metode penelitian}

Rancangan percobaan pada petak uji perolehan genetik adalah rancangan acak lengkap berblok/randomized complete block design (RCBD) dengan perlakuan berupa sumber benih dari empat kebun benih semai (KBS) dan satu sumber benih kontrol yang tidak dimuliakan 
dari satu areal produksi benih (APB). Setiap perlakuan sumber benih ditanam sebanyak 225 pohon per plot dengan konfigurasi 15 pohon x 15 pohon, masing-masing plot diulang sebanyak 4 blok (ulangan) dan jarak tanam $2 \mathrm{~m} \times 2 \mathrm{~m}$ (Nirsatmanto et al., 2009).

Tabel 1. Deskripsi lokasi petak uji perolehan genetik A. mangium di Jonggol, Jawa Barat

\begin{tabular}{lll}
\hline Garis Lintang & $:$ & $06^{0} 20^{\prime} 59^{\prime \prime} \mathrm{LS}-06^{0} 27^{\prime} 01^{\prime \prime} \mathrm{LS}$ \\
Garis Bujur & $:$ & $106^{0} 26^{\prime} 03^{\prime \prime} \mathrm{BT}-106^{0} 35^{\prime} 16^{\prime \prime} \mathrm{BT}$ \\
Tinggi tempat & $:$ & $450 \mathrm{mdpl}$ \\
Rata - rata curah hujan tahunan & $:$ & $2500 \mathrm{~mm} / \mathrm{th}$ \\
Jenis tanah & $:$ & Podzolik merah kuning \\
Iklim & $:$ & A (Schmidt dan Ferguson) \\
Suhu maksimum & $:$ & $26^{\circ} \mathrm{C}$ \\
Suhu minimum & $:$ & $18^{\circ} \mathrm{C}$ \\
Kelerengan & $:$ & $10 \%$ \\
\hline
\end{tabular}

Sumber: $\quad$ Perum Perhutani KPH Bogor, 2011

Tabel 2. Informasi sumber benih yang diuji pada uji perolehan genetik A. mangium di Jonggol, Jawa Barat

\begin{tabular}{|c|c|c|c|c|}
\hline No. & Sumber benih & Lokasi & Sumber provenansi & Keterangan \\
\hline 1 & KBS-2 & Pendopo, Sumatera Selatan & Oriomo, Kini, Wipim (PNG) & Generasi pertama $(\mathrm{F}-1)^{1}$ \\
\hline 2 & KBS-5 & Wonogiri, Jawa Tengah & $\begin{array}{l}\text { Claudie River, Pascoe River, } \\
\text { Scrubby CK, Cassowary (QLD) } \\
\text { Oriomo, Kini, Wipim ,Morehead, } \\
\text { Dimisisi, Derideri, Arufi Village, } \\
\text { Bimadebun(PNG) }\end{array}$ & Generasi pertama $(\mathrm{F}-1)^{2}$ \\
\hline 3 & KBS-19 & Pleihari, Kalimantan Selatan & Pascoe River (QLD) & Generasi kedua $(\mathrm{F}-2)^{3}$ \\
\hline 4 & KBS-20 & Wonogiri, Jawa Tengah & $\begin{array}{l}\text { Claudie River, Pascoe River, } \\
\text { Scrubby CK, Cassowary (QLD) } \\
\text { Oriomo, Kini, Wipim,Morehead, } \\
\text { Dimisisi, Derideri, Arufi Village, } \\
\text { Bimadebun(PNG) }\end{array}$ & Generasi kedua $(\mathrm{F}-2)^{4}$ \\
\hline 5 & APB & Subanjeriji, Sumatera Selatan & - & tidak termuliakan \\
\hline
\end{tabular}

Sumber : $\quad{ }^{1}$ Kurinobu, Nirsatmanto, \& Susanto, $1994 ;{ }^{2}$ Nirsatmanto \& Hashimoto, $1995 ;{ }^{3}$ Osamu \& Leksono, 2001; ${ }^{4}$ Leksono, Nirsatmanto, Setyaji, \& Surip, 2005

Keterangan:

KBS : Kebun Benih Semai

APB : Areal Produksi Benih

PNG : Papua Nugini

QLD : Queensland-Australia

Pengumpulan data dilakukan melalui pengukuran beberapa parameter pertumbuhan meliputi tinggi total pohon, diameter batang setinggi dada, kelurusan batang, volume batang dan volume tegakan. Pengukuran tinggi total pohon dan diameter batang menggunakan skala metrik. Sedangkan untuk kelurusan batang dilakukan dengan menggunakan sistem skoring dari 1 sampai dengan 5 didasarkan pada tingkat kelurusan batang dengan kriteria sebagai berikut: a) Skor 1: lengkungan batang > diameter batang b) Skor 2: lengkungan batang $\geq 3 / 4$ diameter batang, tetapi kurang dari diameter batang

c) Skor 3: lengkungan batang $\geq 1 / 2$ diameter batang, tetapi kurang dari $3 / 4$ diameter batang

d) Skor 4: lengkungan batang $<1 / 2$ diameter batang

e) Skor 5: tidak terdapat lengkungan (lurus)

Untuk mengurangi bias karena persaingan pertumbuhan antar petak, pengukuran pada setiap petak dilakukan hanya pada baris dan jalur tanaman bagian dalam, yaitu ukuran $9 \times 9$ pohon. 
Pada petak uji perolehan genetik ini terdapat satu blok yang terbakar, sehingga pengumpulan data hanya dilakukan pada tiga blok.

Sebagai fungsi dari tinggi dan diameter, maka volume batang $\left(V_{i}\right)$ dihitung pada setiap individu pohon dengan menggunakan persamaan (Inose, Nakamura, \& Saridi, 1991) :

$V_{i}=0,000058806 \times D^{1.71772} \times H^{1.0809}$

dengan $D=$ diameter batang, dan $H=$ tinggi total pohon.

Selanjutnya volume tegakan $\left(V_{s}\right)$ per hektar dihitung dengan melakukan konversi total volume tegakan pada setiap plot ke dalam volume tegakan per hektar dengan rumus sebagai berikut:

$V_{S}=\frac{\text { total volume per plot }}{\text { luas area per plot dalam } m^{2}} \times 10000$

Nilai perolehan genetik aktual $(\Delta \mathrm{G})$ dihitung sebagai selisih antara KBS dengan APB atau kontrol dengan rumus sebagai berikut:

$\Delta G=\frac{K B S-A P B}{A P B} X 100$

\section{Analisis data}

Analisis data dilakukan menggunakan analisis varians (ANOVA), dan apabila terdapat perbedaan yang nyata antar perlakuan dilakukan uji lanjut menggunakan DMRT (Duncan's Multiple Range Test). Adapun model linier yang dipergunakan dalam penelitian ini adalah:

$Y_{i j}=\mu+B_{i}+K_{j}+E_{i j}$

dengan $Y_{i j}, \mu, B_{i}, K_{j}$, dan $E_{i j}$ berturut-turut adalah parameter yang diukur, rata-rata umum, pengaruh blok ke- $i$, pengaruh sumber benih ke- $j$ dan random error pada pengukuran ke-ij.

\section{HASIL DAN PEMBAHASAN}

\section{A. Pertumbuhan tanaman}

Hasil pengukuran rata-rata pertumbuhan dan kelurusan batang pada petak uji perolehan genetik A. mangium umur dua, tiga, dan empat tahun disajikan pada Tabel 3. Secara umum, pada umur dua, tiga, dan empat tahun tanaman di petak uji perolehan genetik menunjukkan pertumbuhan yang baik. Pada umur empat tahun tinggi mencapai $14,32 \mathrm{~m}$, diameter $13,02 \mathrm{~cm}$, dan volume batang $0,103 \mathrm{~m}^{3}$. Sementara itu rata-rata riap tahunan berkisar antara 2,55-3,07 m/tahun untuk tinggi; $1,52-1,86 \mathrm{~cm} /$ tahun untuk diameter dan $0,03-0,04 \mathrm{~m}^{3} /$ tahun untuk volume pohon. Dari empat kebun benih yang diamati, peningkatan riap tahunan tertinggi terdapat pada kebun benih generasi kedua (KBS-19 dan KBS20). Disisi lain peningkatan riap kebun benih generasi pertama (KBS-2 dan KBS-5) menunjukkan kecenderungan yang lebih kecil apabila dibandingkan dengan APB pada periode umur 3-4 tahun. Hal ini menunjukkan bahwa adanya tingkat persaingan antar pohon pada tegakan dengan kerapatan yang tinggi telah memberikan pengaruh yang berbeda terhadap pertumbuhan benih unggul $A$. mangium yang berasal dari beberapa sumber benih.

Disamping memengaruhi pertumbuhan tinggi, diameter dan volume batang, penggunaan benih unggul dari KBS berdampak pada peningkatan kelurusan batang seiring bertambahnya umur tanaman. Hal ini terlihat pada Tabel 3, dengan rata-rata bentuk batang meningkat dari kisaran 2,45 - 2,71 pada umur 2 tahun menjadi 3,45 - 3,73 pada umur empat tahun. Rata-rata kelurusan batang pada kebun benih semai generasi kedua (KBS-19 dan KBS20) memiliki kencenderungan yang lebih baik dibandingkan dengan kebun benih semai generasi pertama (KBS-2 dan KBS-5). Demikian halnya jika dibandingkan dengan APB, secara umum benih unggul dari kebun benih semai mempunyai kelurusan batang yang lebih baik, khususnya pada umur empat tahun. Hasil pengamatan terhadap pertumbuhan dan bentuk batang sebagaimana diuraikan di atas menunjukkan bahwa perbedaan kualitas genetik materi pertanaman A. mangium akan memberikan tanggapan yang berbeda terhadap adanya persaingan antar pohon (inter-tree competition). Informasi adanya perbedaan respon ini sangat bermanfaat dalam pengembangan benih unggul hasil pemuliaan 
A. mangium pada tataran pertanaman operasional, khususnya pertanaman untuk suplai bahan baku pertukangan melalui strategi pengaturan kerapatan tegakan awal dan tindakan penjarangan.

\section{B. Volume tegakan}

Secara umum, pada umur dua, tiga, dan empat tahun tanaman $A$. mangium di petak uji perolehan genetik menunjukkan produktivitas tegakan yang baik. Volume tegakan mengalami peningkatan dari $58,56 \mathrm{~m}^{3} /$ ha (umur dua tahun), $94,87 \mathrm{~m}^{3 /}$ ha (umur tiga tahun) dan $163,80 \mathrm{~m}^{3} / \mathrm{ha}$ (umur empat tahun). Rasio peningkatan riap volume tegakan menunjukkan bahwa pada periode umur 2 - 3 tahun, keempat kebun benih semai yang diuji menunjukkan kecenderungan riap yang hampir sama (Gambar 1). Namun demikian pada umur 3 - 4 tahun, KBS-19 dan KBS-20 menunjukkan peningkatan riap yang lebih tinggi dibandingkan dengan KBS-2 dan KBS-5. Hal ini memberikan petunjuk bahwa tingkat persaingan antar pohon dalam tegakan di plot uji perolehan genetik telah memberikan dampak pada saat tanaman mulai umur tiga tahun, khususnya terhadap benih unggul dari KBS-2 dan KBS-5. Disamping itu faktor genetik diduga ikut memengaruhi munculnya perbedaan peningkatan riap pada umur 3 - 4 tahun antara keempat kebun benih yang diuji. Hal ini dimungkinkan, mengingat bahwa keempat kebun benih yang diuji disini memiliki latar belakang genetik (genetic background) yang berbeda (Tabel 1).

Secara umum sumber benih dari empat kebun benih semai menunjukkan pertumbuhan volume tegakan yang lebih baik dibandingkan dengan sumber benih yang tidak dimuliakan dari APB (kontrol), walaupun pada umur dua dan tiga tahun hasil analisis varians tidak menunjukkan perbedaan yang nyata (Tabel 4). Sumber benih mulai memberikan pengaruh yang nyata pada volume tegakan setelah tanaman berumur empat tahun. Hal ini mengindikasikan kuatnya pengaruh faktor genetik terhadap produktivitas volume tegakan seiring dengan meningkatnya umur tanaman dan tingkat persaingan antar pohon pada umur empat tahun sebagaimana diuraikan pada paragraf sebelumnya.

Hasil uji lanjut DMRT membuktikan bahwa sumber benih dari empat kebun benih semai berada pada urutan yang lebih baik dibandingkan dengan benih kontrol pada seluruh umur pengamatan (Tabel 5), walaupun pada umur dua dan tiga tahun tidak menunjukkan perbedaan yang nyata (Tabel 4). Di antara empat kebun benih yang diuji, urutan produktivitas volume tegakan menunjukkan angka yang beragam pada umur dua, tiga, dan empat tahun, kecuali pada KBS-20 yang cenderung selalu menduduki urutan tertinggi. KBS-2 dan KBS-5 cenderung menunjukkan urutan semakin menurun seiring dengan perkembangan umur tanaman. Sementara itu KBS-19 cenderung menunjukkan rangking semakin naik pada umur empat tahun.

Perbedaan rangking pada umur dua, tiga, dan empat tahun memberikan petunjuk bahwa terdapat perbedaan tanggapan sumber benih dari empat kebun benih semai terhadap persaingan antar individu pohon di dalam masing-masing petak. Benih unggul dari kebun benih generasi pertama (KBS-2 dan KBS-5) cenderung mengalami penurunan rangking seiring dengan bertambahnya umur. Sementara itu benih unggul dari kebun benih generasi kedua (KBS-19 dan KBS-20) cenderung mengalami kenaikan ranking seiring dengan bertambahnya umur. Hal ini diduga karena adanya perbedaan tingkat toleransi benih unggul terhadap kompetisi antar pohon. Persaingan antar individu pohon akan semakin kuat seiring dengan perkembangan umur tanaman pada tegakan yang tidak dilakukan penjarangan. Sebagaimana diketahui bahwa volume tegakan $\left(\mathrm{m}^{3} / \mathrm{ha}\right)$ merupakan fungsi dari volume batang dan kerapatan tegakan. Kerapatan tegakan sebanyak 2500 pohon per hektar (jarak tanam $2 \times 2 \mathrm{~m}$ ) merupakan kerapatan yang cukup tinggi bagi pertumbuhan $A$. mangium sebagai salah satu jenis tanaman hutan cepat tumbuh. 
Tabel 3. Rata-rata pertumbuhan A. mangium dari beberapa sumber benih yang diuji pada uji perolehan genetik di Jonggol, Jawa Barat

\begin{tabular}{|c|c|c|c|c|c|c|c|c|c|c|c|c|}
\hline \multirow[b]{3}{*}{ Populasi } & \multicolumn{12}{|c|}{ Umur (Tahun) } \\
\hline & \multicolumn{4}{|c|}{2} & \multicolumn{4}{|c|}{3} & \multicolumn{4}{|c|}{4} \\
\hline & $\begin{array}{l}\text { Tinggi } \\
(\mathrm{m})\end{array}$ & $\begin{array}{l}\mathrm{DBH} \\
(\mathrm{cm})\end{array}$ & $\begin{array}{c}\text { Kelurusan } \\
\text { Batang }\end{array}$ & $\begin{array}{c}\text { Volume } \\
\text { pohon } \\
\left(\mathrm{m}^{3}\right)\end{array}$ & $\begin{array}{l}\text { Tinggi } \\
\text { (m) }\end{array}$ & $\begin{array}{c}\mathrm{DBH} \\
(\mathrm{cm})\end{array}$ & $\begin{array}{c}\text { Kelurusan } \\
\text { Batang }\end{array}$ & $\begin{array}{c}\text { Volume } \\
\text { pohon } \\
\left(\mathrm{m}^{3}\right)\end{array}$ & $\begin{array}{l}\text { Tinggi } \\
\text { (m) }\end{array}$ & $\begin{array}{c}\mathrm{DBH} \\
(\mathrm{cm})\end{array}$ & $\begin{array}{c}\text { Kelurusan } \\
\text { Batang }\end{array}$ & $\begin{array}{l}\text { Volume } \\
\text { pohon } \\
\left(\mathrm{m}^{3}\right)\end{array}$ \\
\hline KBS-2 & 8,60 & 9,61 & 2,45 & 0,028 & 11,75 & 11,49 & 3,46 & 0,059 & 13,91 & 12,65 & 3,45 & 0,097 \\
\hline KBS-5 & 8,97 & 9,59 & 2,71 & 0,030 & 11,47 & 11,47 & 3,22 & 0,056 & 14,08 & 12,80 & 3,73 & 0,097 \\
\hline KBS-19 & 8,63 & 10,08 & 2,71 & 0,029 & 10,68 & 12,03 & 3,31 & 0,052 & 14,77 & 13,46 & 3,57 & 0,111 \\
\hline KBS-20 & 8,98 & 9,99 & 2,49 & 0,032 & 11,64 & 12,04 & 3,46 & 0,061 & 14,58 & 13,26 & 3,60 & 0,108 \\
\hline APB & 8,29 & 9,21 & 2,80 & 0,026 & 10,73 & 11,61 & 3,44 & 0,052 & 14,23 & 12,94 & 3,39 & 0,101 \\
\hline Rerata & 8,70 & 9,70 & 2,63 & 0,029 & 11,27 & 11,73 & 3,38 & 0,056 & 14,32 & 13,02 & 3,55 & 0,103 \\
\hline
\end{tabular}

Keterangan: DBH : Diameter setinggi dada

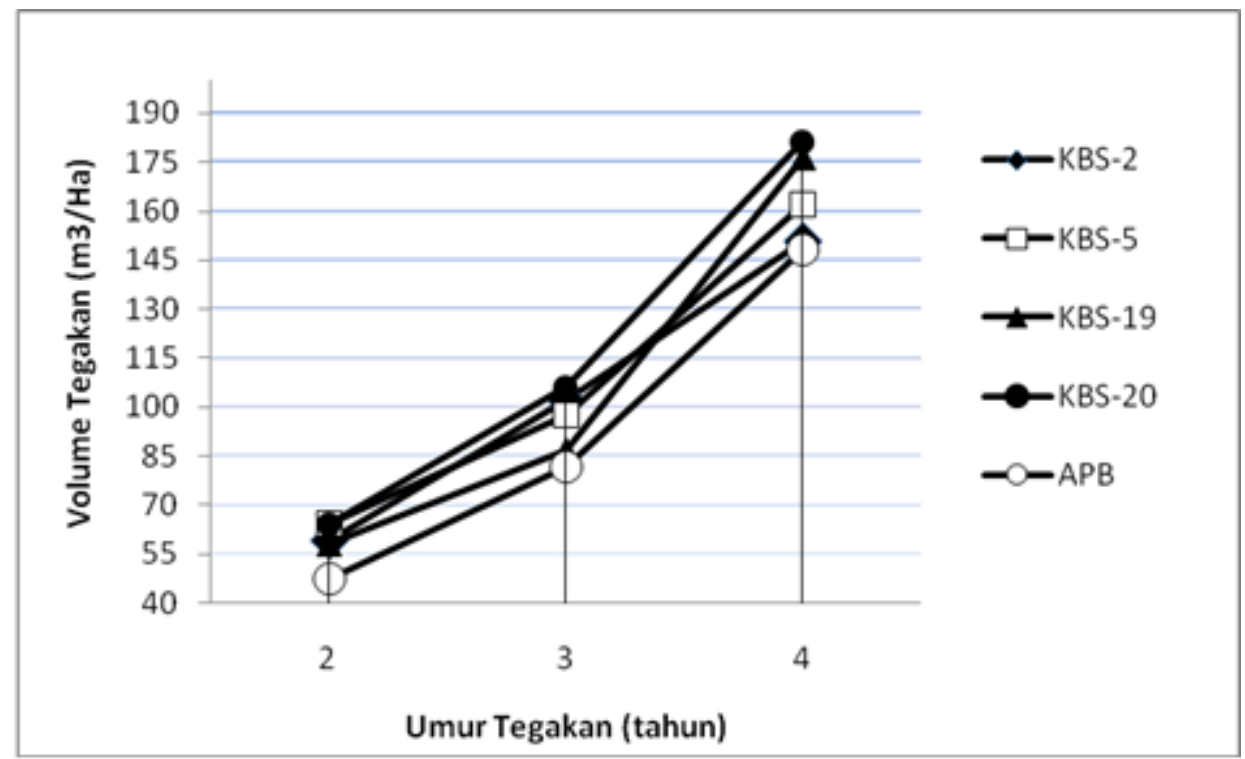

Gambar 1. Produktivitas volume tegakan (m3/ha) umur 2, 3 dan 4 tahun pada petak uji perolehan genetik A. mangium di Jonggol, Jawa Barat

Perbedaan tanggapan sumber benih dari empat kebun benih menunjukkan bahwa terdapat pengaruh genetik pada aras sumber benih terhadap kerapatan tegakan yang tinggi. Pengaruh genetik ini diduga karena adanya perbedaan intensitas seleksi yang digunakan pada empat kebun benih yang diuji. KBS-2 dan KBS-5 merupakan kebun benih semai generasi pertama, sedangkan KBS-19 dan KBS-20 merupakan kebun benih semai generasi kedua (Tabel 2). Seluruh kebun benih semai yang diuji di sini dibangun dengan sistem seleksi berulang (recurrent selection system), sehingga semakin tinggi siklus generasi pemuliaan yang dilakukan dapat diartikan sebagai semakin tingginya intensitas seleksi yang digunakan. White, Adam, dan Neale (2007) melaporkan bahwa semakin tinggi intensitas seleksi yang diterapkan pada suatu kebun benih cenderung akan meningkatkan daya tahan sumber benih yang dihasilkan terhadap persaingan antar pohon dalam tegakan. Dengan demikian walaupun telah terjadi penurunan rasio angka bertahan hidup $( \pm$ 13,49\%), KBS-19 dan KBS-20 dalam penelitian ini telah memberikan petunjuk adanya daya tahan yang lebih tinggi terhadap kerapatan awal tegakan 2500/hektar dan daya tahan ini berbeda nyata pada umur empat tahun. Kondisi ini tampak nyata khususnya pada KBS-20 yang merupakan kebun benih semai komposit generasi 
kedua yang dibangun menggunakan 40 famili yang berasal dari masing-masing 10 pohon plus dari famili terbaik di empat kebun benih semai generasi pertama dari empat sumber provenansi (Leksono et al., 2005). Hal ini juga terlihat dari hasil peningkatan riap (Gambar 1), karena pada periode umur 3 - 4 tahun KBS-19 dan KBS-20 memiliki riap volume tegakan yang lebih tinggi dibandingkan dengan dua kebun benih semai lainnya.

Tabel 4. Analisis varians volume tegakan pada petak uji perolehan genetik A. mangium di Jonggol, Jawa Barat

\begin{tabular}{lcccc}
\hline \multirow{2}{*}{ Sumber Ragam } & derajat & \multicolumn{3}{c}{ RerataKuadrat } \\
\cline { 3 - 5 } & bebas & 2 Tahun & 3 Tahun & 4 Tahun \\
\hline Blok & 2 & $262,631 \mathrm{~ns}$ & $103,923 \mathrm{~ns}$ & $109,739 \mathrm{~ns}$ \\
Sumber Benih & 4 & $144,668 \mathrm{~ns}$ & $324,053 \mathrm{~ns}$ & $657,969^{*}$ \\
Eror & 8 & 91,480 & 196,997 & 137,396 \\
\hline
\end{tabular}

* : berbeda nyata pada taraf $5 \%$

ns : tidak berbeda nyata

Tabel 5. Volume tegakan pada petak uji perolehan genetik A. mangium di Jonggol, Jawa Barat

\begin{tabular}{|c|c|c|c|c|c|c|}
\hline \multirow[b]{2}{*}{ Populasi } & \multicolumn{2}{|c|}{2 Tahun } & \multicolumn{2}{|c|}{3 Tahun } & \multicolumn{2}{|c|}{4 Tahun } \\
\hline & $\begin{array}{l}\text { Volume } \\
\left(\mathrm{m}^{3} / \mathrm{Ha}\right)\end{array}$ & Rangking & $\begin{array}{l}\text { Volume } \\
\left(\mathrm{m}^{3} / \mathrm{Ha}\right)\end{array}$ & Rangking & $\begin{array}{l}\text { Volume } \\
\left(\mathrm{m}^{3} / \mathrm{Ha}\right)\end{array}$ & Rangking \\
\hline KBS-2 & 59,16 a & 3 & $102,23 \mathrm{a}$ & 2 & $150,95 \mathrm{~b}$ & 4 \\
\hline KBS-5 & $64,39 \mathrm{a}$ & 1 & $97,57 \mathrm{a}$ & 3 & $162,16 \mathrm{ab}$ & 3 \\
\hline KBS-19 & $57,92 \mathrm{a}$ & 4 & $86,70 \mathrm{a}$ & 4 & $176,34 \mathrm{a}$ & 2 \\
\hline KBS-20 & $64,07 \mathrm{a}$ & 2 & $106,23 \mathrm{a}$ & 1 & 181,35 a & 1 \\
\hline APB & $47,26 \mathrm{a}$ & 5 & $81,64 \mathrm{a}$ & 5 & $148,18 \mathrm{~b}$ & 5 \\
\hline Rata-rata & 58,56 & & 94,87 & & 163,80 & \\
\hline
\end{tabular}

Keterangan: Huruf yang sama menunjukkan tidak beda nyata

Berdasarkan pola kecenderungan pertumbuhan volume tegakan, disarankan bahwa pada tataran operasional perlu dilakukan manajemen pola silvikultur yang berbeda di antara empat kebun benih semai A. mangium yang diuji, khususnya berkaitan dengan tindakan penjarangan. Pada kerapatan awal tegakan yang tinggi (2500 pohon/ha), umur tiga tahun telah menunjukkan adanya dampak negatif terhadap volume tegakan yang ditandai dengan mulai menurunnya riap volume tegakan, khususnya pada KBS-2 dan KBS-5 (Gambar 1). Oleh karena itu pada tegakan yang ditanam menggunakan sumber benih dari kedua kebun benih ini perlu dilakukan penjarangan sejak umur tiga tahun untuk mengantisipasi terjadinya penurunan produktivitas. Sebaliknya, pada tegakan yang ditanam menggunakan sumber benih dari kebun benih yang lebih tahan terhadap kerapatan awal tegakan yang tinggi, yaitu dari KBS-19 dan KBS-20, tindakan penjarangan dapat dilakukan
1- 2 tahun lebih lambat dibandingkan KBS-2 dan KBS-5. Penundaan tindakan penjarangan di tegakan A. mangium yang lebih toleran terhadap kerapatan tegakan yang tinggi akan memberikan dampak positif terhadap peningkatan kualitas batang (kelurusan batang) sehingga sangat sesuai dalam mendukung penyediaan bahan baku untuk kayu pertukangan yang berkualitas.

\section{Perolehan genetik aktual}

Hasil penghitungan perolehan genetik aktual untuk volume tegakan dari masing-masing kebun benih terhadap kontrol menunjukkan nilai yang positif (Gambar 2). Perolehan genetik cenderung menunjukkan nilai yang semakin menurun seiring dengan bertambahnya umur tegakan, yaitu 30\% (umur dua tahun), 20\% (umur tiga tahun) dan $13 \%$ (umur empat tahun). 


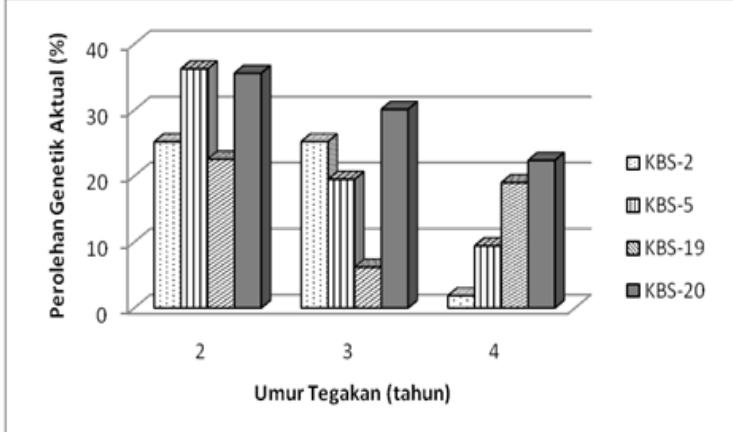

Gambar 2. Perolehan genetik aktual umur 2, 3 dan 4 tahun pada petak uji perolehan genetik A. mangium di Jonggol, Jawa Barat

Secara umum perolehan genetik aktual volume tegakan terbesar ditemukan pada KBS-20 dan terkecil pada KBS-2. Hal ini memberikan petunjuk bahwa tegakan yang kurang toleran terhadap kerapatan tegakan yang tinggi akan mengalami penurunan nilai perolehan genetik aktual volume tegakan yang lebih besar seiring dengan semakin tingginya tingkat persaingan antar individu pohon dalam tegakan. Eldridge (1982), Zobel dan Talbert (1991) menyatakan bahwa nilai perolehan genetik akan cenderung menurun seiring dengan perkembangan pertumbuhan tegakan dan naiknya tingkat persaingan antar pohon. Walaupun perbandingan secara langsung sebenarnya tidak dapat dilakukan karena adanya perbedaan lokasi dan pola silvikultur yang diterapkan, perolehan genetik pada penelitian ini secara umum menunjukkan angka yang lebih rendah dibandingkan perolehan genetik aktual yang dilakukan oleh Nirsatmanto et al. (2014) yaitu sebesar > 50\% pada kerapatan tegakan 1250 pohon/hektar.

Dampak penggunaan benih unggul A. mangium pada kerapatan tegakan yang tinggi terhadap produktivitas tegakan sebagaimana hasil dari penelitian ini memberi implikasi dalam proses pemuliaan tanaman. Penentuan tingkat intensitas seleksi pada kebun benih semai A. mangium perlu mempertimbangkan pola silvikultur yang akan diterapkan di pertanaman, khususnya berkaitan dengan potensi terjadinya persaingan antar pohon dalam tegakan dan tindakan penjarangan. Produktivitas volume tegakan dan potensi perolehan genetik benih unggul A. mangium akan dapat ditingkatkan di tegakan yang lebih toleran terhadap persaingan antar individu pohon. Benih unggul A. mangium untuk pertanaman sebagai bahan baku industri kayu pertukangan yang ditanam dengan pola silvikultur kerapatan tegakan awal yang tinggi dan diikuti dengan tindakan penjarangan perlu mempertimbangkan informasi intensitas seleksi yang dipergunakan dalam proses pemuliaannya. Informasi ini sangat penting untuk mengetahui tingkat toleransi benih unggul terhadap kerapatan tegakan yang tinggi sehingga tata waktu kegiatan penjarangan bisa dilakukan lebih tepat dan potensi kehilangan perolehan genetik bisa dicegah.

\section{KESIMPULAN}

Pengujian pada kerapatan awal tegakan yang tinggi (2500 pohon/hektar) di petak uji perolehan genetik di Jonggol, Jawa Barat menunjukkan bahwa benih unggul A. mangium yang dihasilkan dari kebun benih semai menunjukkan produktivitas volume tegakan yang lebih tinggi dibandingkan benih kontrol yang tidak dimuliakan. Perbedaan intensitas seleksi benih unggul A. mangium dari beberapa kebun benih semai memberikan tingkat ketahanan yang berbeda terhadap kerapatan tegakan yang tinggi. Semakin tinggi intesitas seleksi yang digunakan dalam proses pemuliaan A. mangium cenderung akan memberikan tingkat ketahanan yang lebih tinggi terhadap persaingan antar individu pohon dalam tegakan.

\section{UCAPAN TERIMA KASIH}

Ucapan terima kasih penulis sampaikan kepada Perum PERHUTANI yang telah membantu menyediakan lahan dan pembangunan petak uji perolehan genetik A. mangium di Jonggol, Jawa Barat. Terima kasih juga disampaikan untuk seluruh anggota Tim Peneliti Populasi Pemuliaan untuk Unggulan Kayu Pulp di BBPPBPTH atas bantuan dan kerjasamanya dalam penelitian ini. 


\section{DAFTAR PUSTAKA}

Eldridge, K. G. (1982). Genetic improvements from a radiata pine seed orchards. New Zealand Journal of Forest Science, 12, 404-411.

Hardiyanto, E. B. (2004). Silvikultur dan Pemuliaan Acacia mangium. In E. B. Hardiyanto \& A. Hardjono (Eds.), Pembangunan hutan tanaman Acacia mangium: pengalaman di PT. Musi Hutan Persada (pp. 207-208). Yogyakarta: Polydoor.

Hardiyanto, E. B., \& Nambiar, E. K. S. (2014). Productivity of successive rotations of Acacia mangium plantations in Sumatra, Indonesia: impacts of harvest and inter-rotation site management. New Forests, 45(4), 557-575. https://doi.org/10.1007/s11056-014-9418-8

Harwood, C. E., Hardiyanto, E. B., \& Yong, W. C. (2015). Genetic improvement of tropical acacias: achievements and challenges. Southern Forests: A Journal of Forest Science, 77(1), 11-18. https://doi.org/10.2989/20702620.2014.9993 02

Hashimoto, K., Kurinobu, S., \& Suhaendi, H. (1996) Establishment of seed sources of tropical tree species in Indonesia. In M. J. Dieters, A. C. Matheson, D. G. Nikles, C. E. Harwood, \& S. M. Walker (Eds.), Tree improvement for sustainable tropical forestry: Proceeding of the QFRI-IUFRO Conference, Caloundra, Australia. 27 October - 1 November 1996 (pp. 370-371). Caloudra, Australia: Queensland Forestry Research Institute.

Hastanto, H. (2010). Peran benih unggul untuk meningkatkan produktivitas hutan tanaman Acacia mangium di PT. Musi Hutan Persada. In B. Leksono, A. Nirsatmanto, \& A. Y. P. B. C. Widyatmoko (Eds.), Prosiding Ekspose Hasil-Hasil Penelitian: Status Terkini Penelitian Pemuliaan Tanaman Hutan 1 Oktober 2009 (pp. 136-146). yogyakarta: Balai Besar Penelitian Bioteknologi dan Pemuliaan Tanaman Hutan.

Inose, M., Nakamura, T., \& Saridi, Z. Bin. (1991). Yield Prediction Table and Estimation of SiteClass by Site Class Indicators on Acacia mangium in SAFODA Plantation. Sabah.

Kurinobu, S., Nirsatmanto, A., \& Susanto, M. (1994). General information of seed source establishment of Acacia mangium in South Sumatera. Yogyakarta.

Kurinobu, S., \& Rimbawanto, A. (2002). Genetic improvement of plantation species in
Indonesia-Summary of Project Achievement (JICA Forest Tree Improvement Phase II). In A. Rimbawanto \& M. Susanto (Eds.), Proceedings of international conference on advances in genetic improvement of tropical tree species, 1-3 October 2002, Yogyakarta, Indonesia. Yogyakarta: Centre for Forest Biotechnology and Tree Improvement.

Leksono, B., Nirsatmanto, A., Setyaji, T., \& Surip. (2005). General information of seed source (F-2) of A. mangium, A. crassicarpa and E. pellita establishment in Wonogiri, Central Java. Yogyakarta.

Leksono, B., Nirsatmanto, A., Wahyuningtyas, R. S., \& Sofyan, A. (2007). Genetic gains trial of first-generation seedling seed orchards of Acacia mangium established in three locations. Jurnal Penelitian Hutan Tanaman, 4(1), 27-39.

Nirsatmanto, A., \& Hashimoto, K. (1995). General information of seed source establishment of Acacia mangium and Eucalyptus pellita in Wonogiri, Central Java. Yogyakarta.

Nirsatmanto, A., \& Setyaji, T. (2013). Trend of Realized Genetic Gain Observed in SecondGeneration Seedling Seed Orchards of Acacia Mangium in South Kalimantan, Indonesia. Indonesian Journal of Forestry Research, 10(1), 57-64. https://doi.org/10.20886/ijfr.2013.10.1.57-64

Nirsatmanto, A., Setyaji, T., Sunarti, S., \& Kartikaningtyas, D. (2015). Genetic gain and projected increase in stand volume from two cycles breeding program of Acacia mangium. Indonesian Journal of Forestry Research, 2(2), 71-79. https://doi.org/http://dx.doi.org/10.20886/ijfr. 2015.2.2.71-79

Nirsatmanto, A., Setyaji, T., \& Surip. (2009). General information of gain trial of F-2 Acacia mangium establishment in Jonggol, West Java (Collaboration with Perum Perhutani). Yogyakarta.

Nirsatmanto, A., Setyaji, T., \& Wahyuningtyas, R. S. (2014). Realized genetic gain and seed source $\mathrm{x}$ interaction on stand volume productivity of Acacia mangium. Indonesian Journal of Forestry Research, 1(1), 21-32. https://doi.org/http://dx.doi.org/10.20886/ijfr. 2014.1.1.21-32

Osamu, C., \& Leksono, B. (2001). General information of seed sources (F2) of Acacia mangium in South Kalimantan. Yogyakarta. 
Perum Perhutani KPH Bogor. (2011). Rencana pengaturan kelestarian hutan jangka tahun 2011 s/d 2015.

Pinyopusarerk, K., Gunn, B. ., \& Liang, S. . (1993) Taxonomy, distribution, biology and use as an exotic. In K. Awang \& D. Taylor (Eds.), Acacia mangium Growing and utilization. Bangkok. Thailand: Winrock International and The Food and FAO.
White, T. W., Adam, W. T., \& Neale, D. B. (2007). Forest genetics. (T. L. White, W. T. Adams, \& D. B. Neale, Eds.). Wallingford: CABI. https://doi.org/10.1079/9781845932855.0000

Zobel, B., \& Talbert, J. (1991). Applied forest tree improvement (7th ed.). Prospect Heights, Illinois: Waveland Press. 